\title{
The Effect of Good Corporate Governance and Firm Size on Financial Performance
}

\author{
Lela Hindasah $^{1, *}$ Edi Supriyono $^{1}$ Lorenza Julia Ningri $^{1}$
}

\author{
${ }^{1}$ Universitas Muhammadiyah Yogyakarta, Indonesia \\ *Corresponding author. Email: lela.hindasah@gmail.com
}

\begin{abstract}
This research aimed to examine the Influence of Good Corporate Governance (GCG) Mechanism and Firm Size of Corporation toward Finance Performance. This research's objects were conventional banking corporations registered at the Indonesian Stock Exchange from 2015 to 2018. The research used 98 samples; the sampling technique employed purposive sampling with specific criteria determined. The data analysis technique utilized was a double linear regression analysis using SPSS. Based on the research's result conducted, the Board of Director had a significant positive influence toward ROA, the Board of Commissioner had a significant positive influence toward ROA, the Institutional Ownership had an insignificant influence toward ROA, the Independent Commissioner had a significant positive influence toward ROA, and the Corporation Size had significant positive influence toward ROA.
\end{abstract}

Keywords: GCG, Board of Director, Board of Commissioner, Institutional Ownership, ROA.

\section{INTRODUCTION}

The economy is developing rapidly in both manufacturing and services. Economic development makes business competition tougher. Banking is one of the sectors affected by economic growth. Banks are an industry that relies on public trust. Therefore, banks must pay attention to their health and image; then, investors believe in investing their money. Dalwai et al. [1]. stated that for the free market to work efficiently, it is important to have elements of accountability, ethics, responsibility, and transparency. According to Bank Indonesia Regulation No. 13/1/PBI/2011 concerning Rating of Commercial Banks, one factor is the implementation of Good Corporate Governance (GCG). The application of GCG is essential in building public or investor confidence. The organization for Economic Co-operation and Development (OECD) defined Corporate Governance (CG) as "a set of relationships between a company's management, its board, its shareholders, and other stakeholders" [2].

The application of GCG can eliminate the banking industry's bad image and protect the public's interests. The implementation of corporate governance has a role in increasing and maximizing banks' value, creating public trust in banks because of bank governance's accountability, openness, fairness, and independence [3]. The mechanism of ownership, supervision, control, and disclosure in corporate governance can reduce conflicts that usually occur, i.e., the company's agency conflicts. Corporate governance refers to the mechanism, processes, and relations by which corporations are controlled and directed [4]. Therefore, companies must implement good corporate governance as an effort to improve company performance and value. Good corporate governance will reduce conflicts between owners and managers and, thus, will lead to improved company performance. The implementation of Good Corporate Governance (GCG) contributes to improved control and management of the company, which can improve company performance. The implementation of GCG is expected to improve the performance because it can make decisions run more effectively and efficiently, the application of GCG can improve services to shareholders. Bachiller [5] GCG can attract investors to invest in the company [6], increase shareholder satisfaction on the company performance, reduce risk [7], and reduce probability financial distress [8].

\section{LITERATURE REVIEW}

The Good Corporate Governance Principles build on four essentials articulated by the OECD (Organization for Economic Co-operation and Development) Business Sector Advisory Group. The four principles of corporate governance articulated in the Millstein Report -- fairness, transparency, accountability, and responsibility [9].

1. Fairness: The OECD Principles expand on the concept of "fairness" with two separate principles. (1) "The corporate governance framework should protect shareholders' rights." (2) "The corporate governance 
framework should ensure the equitable treatment of all shareholders."

2. Transparency: "The corporate governance framework should ensure that timely and accurate disclosure is made on all material matters regarding the corporation."

3. Accountability: "The corporate governance framework should ensure the strategic guidance of the company, the effective monitoring of management by the board, and the board's accountability to the company and the shareholders."

4. Responsibility: "The corporate governance framework should recognize the rights of stakeholders."

GCG is a structure used by companies to regulate company management to increase shareholder value in the long term. In fact, the implementation of GCG in Indonesia is still weak. The application of GCG is needed by companies to survive in the increasingly fierce competition in the globalization era. The company also needs to follow business rules and business ethics well to establish a transparent, healthy, efficient, and conducive business. GCG can make a company better in terms of relationships among owners or shareholders, management, employees, and others.

Previous research examining the effect of Good Corporate Governance showed different results. The result of [10], showed that Good Corporate Governance had a positive and significant effect on financial performance, as measured by Earning Per Share (EPS) and Return on Assets (ROA). These results are consistent with the statement of [20], that good corporate governance, as measured by the number of boards of directors, showed the greater the size of the directors, the better the organization performance. The results of [12], [13] revealed that GCG influenced performance. Besides, [14] uncovered that GCG affected operational efficiency. These studies' results are different from the results of Narwal and Shweta's (2016) research, which delivered that governance variables had no significant effect on productivity. Likewise, [15] disclosed that good corporate governance did not significantly affect performance. The study's results of [16] indicated that the GCG mechanism did not significantly influence performance; it was because GCG was only a formality. Further, the research conducted by [15] found that Corporate Governance quality had no significant impact on performance.

Based on the research mentioned above, the results are inconsistent, so this study reexamined how good corporate governance mechanisms affects bank financial performance. The hypothesis in this study is provided as follows:

H1: The Board of Directors has a significant positive effect on financial performance.
H2: The Board of Commissioners has a significant positive effect on financial performance.

H3: Institutional ownership has a significant positive effect on financial performance.

H4: The independent commissioners have a significant positive effect on financial performance.

H5: The size of a corporation has a significant positive effect on the level of financial performance.

\section{RESEARCH MODEL}

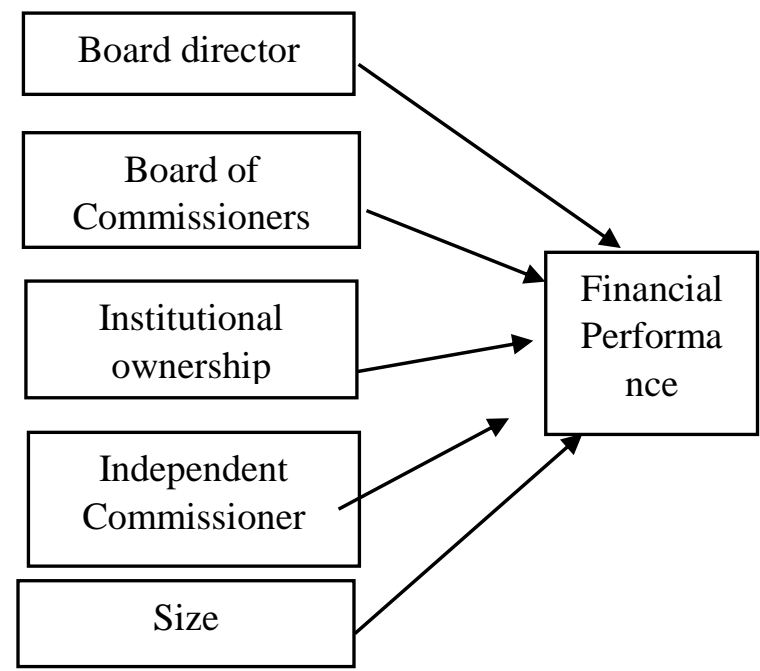

Figure 1. Research Model

\section{METHODOLOGY}

The research objects were the conventional banking companies listed on the Indonesia Stock Exchange (IDX) during the 2015-2018 period. The research samples were 98 samples. The dependent variable of financial performance in this study was measured by the ratio of Return on Assets [4]. The Board of Directors was based on the number of directors, the Board of Commissioners was based on the number of the board of commissioners, and Institutional Ownership was based on the percentage of institutional share ownership. The Independent commissioners were based on the percentage of independent commissioners, and the company size was based on the number of assets measured by Ln's total assets [4].

This research employed multiple linear regression analysis model. The regression equation in this study is as follows: 
$\mathrm{FP}=\mathrm{a}+\mathrm{b}_{1} \mathrm{BD}+\mathrm{b}_{2} \mathrm{CB}+\mathrm{b}_{3} \mathrm{IO}+\mathrm{b}_{4} \mathrm{IC}+\mathrm{b}_{5} \mathrm{SIZE}+\mathrm{e}$

Description:

FF = Financial Performance

$\mathrm{BD}=$ Board Director

$\mathrm{CB}=$ Commissioner Board

$\mathrm{IO}=$ Institutional ownership

$\mathrm{IC}=$ Independent Commissioner

SIZE $=$ bank size

$\mathrm{a}=$ Constanta

b1, b2, b3, b4, b5= Regression Coefficient

$\mathrm{e}=$ Error

\section{RESULTS \& ANALYSIS}

Table 1. Statistical Descriptive

\begin{tabular}{|l|l|l|l|l|l|}
\hline & $\mathrm{N}$ & Min & Max & Mean & $\begin{array}{c}\text { Std. } \\
\text { Deviation }\end{array}$ \\
\hline $\begin{array}{l}\text { Board of } \\
\text { Director }\end{array}$ & 98 & 2 & 12 & 6,71 & 2,504 \\
\hline $\begin{array}{l}\text { Board of } \\
\text { Commissioner }\end{array}$ & 98 & 2 & 9 & 4,9 & 2,008 \\
\hline $\begin{array}{l}\text { Institutional } \\
\text { ownership }\end{array}$ & 98 & 0.86 & 100.00 & 60.8624 & 24.91704 \\
\hline $\begin{array}{l}\text { Independent } \\
\text { Commissioner }\end{array}$ & 98 & 0.33 & 0.75 & 0.5753 & 0.09998 \\
\hline \begin{tabular}{l} 
Size \\
\hline Financial \\
Performance
\end{tabular} & 98 & 22.40 & 34.35 & 30.3775 & 2.85323 \\
\hline
\end{tabular}

\section{Hypothesis Test}

Table 2. t-Test

\begin{tabular}{|c|c|c|c|c|}
\hline \multirow[t]{2}{*}{ Variable } & $\begin{array}{c}\text { Unstandardized } \\
\text { Coefficients } \\
\end{array}$ & \multirow[t]{2}{*}{$\mathrm{T}$} & \multirow[t]{2}{*}{ Sig. } & \multirow[t]{2}{*}{ Description } \\
\hline & $\mathrm{B}$ & & & \\
\hline (Constant) & -11.276 & -2.974 & 0.004 & \\
\hline $\begin{array}{l}\text { Board of } \\
\text { Director }\end{array}$ & 0.663 & 2.394 & 0.019 & Significant \\
\hline $\begin{array}{c}\text { Board of } \\
\text { Commissioner }\end{array}$ & 0.591 & 2.161 & 0.033 & Significant \\
\hline $\begin{array}{r}\text { Institutional } \\
\text { ownership }\end{array}$ & 0.079 & 0.709 & 0.480 & $\begin{array}{c}\text { Not } \\
\text { Significant }\end{array}$ \\
\hline \begin{tabular}{|c} 
Independent \\
Commission \\
er \\
\end{tabular} & 1.261 & 2.387 & 0.019 & Significant \\
\hline Company size & 2.728 & 2.388 & 0.019 & Significant \\
\hline $\begin{array}{c}\text { F test } \\
\text { Sig }\end{array}$ & & $\begin{array}{r}11.5 \\
0,0 \\
\end{array}$ & & \\
\hline
\end{tabular}

Based on table 2, the board of directors, the Board of Commissioners, independent commissioners, and company size positively and significantly affected financial performance.

\section{DISCUSSION}

The Board of Directors positively and significantly influenced Financial Performance. This research's result is also supported by the agency theory, stating that the monitoring process will decrease the errors often happened in managing the company's financial statement, which can be detrimental to various parties in the company. Good monitoring can reduce agency problems, which can help companies achieve their goals and improve the company's financial performance [17]. Thus, the more the number of the board of directors' members in a company, the better the management and control of the company carried out by managers to act according to company goals. It means that with a large number of boards of directors, managers can determine the right strategy for the company to improve the company's financial performance. It is supported by the study by [20].

The Board of Commissioners had a positive and significant effect on financial performance. This opinion is also supported by agency theory, which states that the monitoring process will prevent errors that often occur in managing the company's financial statements that can be detrimental to various parties. Good monitoring can reduce agency problems that can help companies achieve company goals so that it can help to achieve company goals that can improve company financial performance [17]. Thus, the more the number of the board of commissioners, the better the board of directors' supervision so that managers are more careful and more active in improving performance. Therefore, better management performance can reduce the occurrence of agency problems that can harm various parties to improve the company's financial performance. The board of commissioners has a role in supervisory activities. This study's results are in line with those studies, stating that the board of commissioners had a significant positive influence on financial performance.

Institutional ownership did not have a significant impact on financial performance. Based on this research's result, the higher the percentage of institutional ownership would not affect financial performance improvement as measured by ROA. It was because institutional ownership was not effective in conducting supervision and institutional ownership, consisting of several investment companies with different objectives, whether long or short term. Besides, most institutional ownership only carried out its duties as a transit investor (temporary shareholding), focusing on the profits earned in the short term.

Independent Commissioners positively affected performance. The existence of an independent commissioner would prevent errors that often occurred in managing the company's financial statements, which could harm various parties. Good monitoring could reduce agency problems to help the company to achieve company goals improving its financial performance. Therefore, the more the number of independent directors, the tighter the supervision conducted on the board of directors, and the 
more just the manager applies shareholders or other stakeholders and the more obedient the company to the rules set. Thus, it will affect the board of directors' decision to achieve company goals that can improve the company's financial performance properly. It is in accordance with the research by [18] which stated that the independent commissioner significantly and positively impacted performance.

Company size had a positive influence on financial performance. Large companies had large assets, usually had more attractiveness and got the community's attention because the greater the assets owned, the more capital would be invested. Besides, there was a great deal of money circulation, generating more profits than small companies. Therefore, the funds or profits generated could improve the company's welfare to improve its quality, which can improve its financial performance. This research supports the study conducted by [4], [18], [19] that revealed that company size had a positive and significant effect on ROA.

\section{CONCLUSION AND RECOMMENDATION}

This research was conducted to determine the effect of Good Corporate Governance(GCG), consisting of Board of Directors, Board of Commissioners, Institutional Ownership, Independent Commissioners, and Company Size on Financial Performance (ROA) in conventional banking companies listed on the Indonesia Stock Exchange in 2015-2018. The data analysis tool used was multiple linear regression, with a total sample of 98 research samples. Based on the analysis results, the Board of Directors, Board of Commissioners, Independent Commissioners, and company size positively and significantly affected financial performance. Meanwhile, Institutional ownership did not significantly affect financial performance. Institutional ownership did not affect company performance because institutional ownership might not effectively conduct supervision since it consisted of several companies with different goals. It was also possible that institutional ownership only carried out its role as a transit investor (temporary shareholding), which focused on profits earned in the short term.

For investors, this research is expected to be used as material for consideration in investing in selected banking companies. It was done by considering published information, including the number of members of the board of directors, the board of commissioners, independent commissioners, and company size.

\section{REFERENCES}

[1] Dalwai, TAR., Basiruddin, R and Rasid, SZA (2015), A Critical Review of Relationship between Corporate Governance and Firm Performance: GCG Banking Sector Perspective, Corporate Governance, Vol 15 No 1

[2] OECD. (2016). Principles of Corporate Governance. Retrieved December 15, from www.oecd.org/corporate/principles-corporategovernance.htm.

[3] Hamdani (2016), Good Corporate Governance, Mitra Wacana Media, Indonesia

[4] Narwal P.K, Shweta P, (2015), Effect of Bank-Specific Variables on the Productivity and Profitability of Banks, International Journal of Productivity and Performance Management, vol 65 no 8, 2016 pp 1057-1074

[5] Bachiller, P., \& Lacella, J. G. (2018). Corporate governance in Spanish saving banks and its relationship with financial and social performance. Management Decision, 56, 828-848.

[6] Saeed, A., Javed, A.Y., Noreen, U (2018), Microfinancing, Governance, and Performance: a South Asian Perspective, Journal of Economic, Finance and Administrative Science, Vol 23 No 46, pp 247-265

[7] HebaAbou-El-Sood, (2017) "Corporate governance structure and capital adequacy: implications to bank risk taking", International Journal of Managerial Finance, Vol. 13 Issue: 2, pp.165-185

[8] Tamimi, H,A,H. (2012), The effect of Corporate Governance on Performance and Financial Distress, Journal of Financial Regulation and Compliance, Vol 20 No 2 pp 169-181

[9] Gregory, Holly J, Simms Marsha E, (1999), “Corporate Governance: What It Is and Why It Matters", 9 Th International Anti-Corruption Conference, Durban, South Africa, 10-15 October

[10] Mardnly, Z, Sulaiman, M, Riad.A., (2018) Corporate Governance and Firm Performance: An Empirical Evidence from Syria, International Journal of Islamic and Middle Finance and Management vol 11 No 4 pp 591-607

[12] Klapper and Love, "Corporate Governance, Investor Protection and Performance in Emerging Markets", Working Paper - The World Bank, 2003

[13] Anthony Q. Aboagye, James Otieku, (2010) "Are Ghanaian MFIs' performance associated with corporate governance?", Corporate Governance: The international journal of business in society, Vol. 10 Issue: 3, pp.307-320

[14]Ghosh, S, (2017) "Corporate governance reforms and bank performance: evidence from the Middle East and North Africa", Corporate Governance: The International Journal of Business in Society, Vol. 17 Issue: 5, pp.822-844

[15] Ajili, H., Abdelfettah, B (2018), Corporate Governance Quality of Islamic Banks: Measurement and Effect on Financial Performance, International Journal of Islamic and Middle Eastern Finance and Management, Vol 11 No 3, pp 470-487

[16] Arora. A and Chandan S. (2016), Corporate governance and firm performance in developing countries: evidence from India, Corporate Governance VOL. 16 NO. 2 2016, pp. 420-436

[17] Jensen, M. C., \& Meckling, W. H. (1976, July). Theory Of The Firm: Managerial Behavior, Agency Costs And Ownership Structure. Journal of Financial Economics.

[18] Tulung, J. E., \& Ramdani, D. (2018). Independence, Size and Performance of The Board an Emerging Market Research. (F. o. University, Ed.) Corporate Ownership, 15(2), Corporate ownership and control, vol 15, 2, pp 201-208

[19] Rostami, S., Rostami, Z., \& Kohansal, S. (2016). The Effect of Governance Components on Return on Assets and Stock Return of Companies Listed in Tehran Stock Exchange. Procedia Economics and Finance.

[20]Lukas, S., \& Basuki, B. (2015). The Implementation Of Good Corporate Governance And Its Impact On The Financial Performance Of Banking Industry Listed In IDX., The International Journal of Accounting and Business Society, vol 23 no 1 pp 47-72 